\title{
The Effect of Foliar Putrescine Application, Ammonium Exposure, and Heat Stress on Antioxidant Compounds in Cauliflower Waste
}

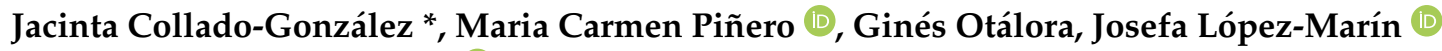 \\ and Francisco M. del Amor *(1)
}

check for updates

Citation: Collado-González, J.;

Piñero, M.C.; Otálora, G.;

López-Marín, J.; Amor, F.M.d. The

Effect of Foliar Putrescine

Application, Ammonium Exposure, and Heat Stress on Antioxidant Compounds in Cauliflower Waste. Antioxidants 2021, 10, 707. https:// doi.org/10.3390/antiox10050707

Academic Editor: Stefania D’Angelo

Received: 26 March 2021

Accepted: 27 April 2021

Published: 29 April 2021

Publisher's Note: MDPI stays neutral with regard to jurisdictional claims in published maps and institutional affiliations.

Copyright: (c) 2021 by the authors. Licensee MDPI, Basel, Switzerland. This article is an open access article distributed under the terms and conditions of the Creative Commons Attribution (CC BY) license (https:/ / creativecommons.org/licenses/by/ $4.0 /)$.
Department of Crop Production and Agri-Technology, Murcia Institute of Agri-Food Research and Development (IMIDA), C/Mayor s/n, 30150 Murcia, Spain; mariac.pinero2@carm.es (M.C.P.); gines.oralora@carm.es (G.O.); josefa.lopez38@carm.es (J.L.-M.)

* Correspondence: jacinta.collado@carm.es (J.C.-G.); franciscom.delamor@carm.es (F.M.d.A.); Tel.: +34-968-36-67-48 (F.M.d.A.); Fax: +34-968-366-733 (F.M.d.A.)

\begin{abstract}
This work has been focused on the study of how we can affect the short heat stress on the bioactive compounds content. Some recent investigations have observed that management of nitrogen fertilization can alleviate short-term heat effects on plants. Additionally, the short-term heat stress can be also ameliorated by using putrescine, a polyamine, due to its crucial role in the adaptation of plants to heat stress Therefore, different $\mathrm{NO}_{3}{ }^{-} / \mathrm{NH}_{4}{ }^{+}$ratios and a foliar putrescine treatment have been used in order to increase tolerance to thermal stress in order to take advantage of the more frequent and intense heat waves and make this crop more sustainable. So, other objective of this work is to make the cauliflower waste more attractive for nutraceutical and pharmaceutical preparations. Thus, the effect of a thermal stress combined with a $50: 50 \mathrm{NO}_{3}{ }^{-} / \mathrm{NH}_{4}{ }^{+}$ratio in the nutrient solution, and the foliar application of $2.5 \mathrm{mM}$ putrescine increased in the content of various sugars (inositol, glucose, and fructose), total phenolic compounds and polyamines, as well as in the antioxidant activity. The greatest accumulation of these compounds was observed in young leaves. Our results show from a physiological and agronomic point of view, that the foliar application of putrescine and the $50: 50 \mathrm{NO}_{3}{ }^{-} / \mathrm{NH}_{4}{ }^{+}$treatment managed to alleviate the negative effects of the abiotic stress suffered at high temperature, yielding plants with higher antioxidant compounds content.
\end{abstract}

Keywords: polyamines; cauliflower waste; heat stress; ammonium; antioxidants

\section{Introduction}

Globally, different types of abiotic stress drastically affect not only the productivity, but also the quality of crops [1]. It is necessary to emphasize stress due to high temperatures, because extreme temperatures, individually or combined with water-deficit conditions, represent a serious threat to agriculture, having a very negative impact on the growth, development, productivity, and quality of cultivated plants [1]. Specifically, during the 20th century, the global temperature increased by $0.5^{\circ} \mathrm{C}$ and by the end of the current century it is expected to have increased by between 1.5 and $5.8{ }^{\circ} \mathrm{C}$ [1]. In recent decades, interest in the effects of climate change with regard to strengthening the intensity of abiotic stress has increased, in order to improve the abiotic stress tolerance of plants [2]. In this sense, previous works have reported that heat stress induces a set of physiological and biochemical reactions in cauliflower metabolism, activating various adaptive processes [3]. Several studies carried out in some plants of Brassicaceae family noticed that if the exposure temperature of these plants exceeds their physiological threshold $\left(32{ }^{\circ} \mathrm{C}\right)$, it can lead to an increase in reactive oxygen species (ROS) within its cells, and oxidative stress may be developed when ROS exceed antioxidant defenses $[3,4]$. Furthermore, it is important to 
take in account that the oxidative stress not only depended on the intensity of heat stress suffered by plants, but also on its duration. Thus, Hussain et al. [5] in a study carried out in Chinese kale (B. alboglabra), it was reported that exposure to high temperature for a long time (greater than 6 days) gave rise to oxidative stress, obtaining a decrease in the content of bioactive compounds.

Spain, specifically Murcia, a region located in the southeast of Spain, is more affected by increasingly frequent heat waves [6,7]. This region is one of the regions with the highest cauliflower and broccoli production in Europe. In fact, the global cauliflower production (combined with broccoli production) amounts to 25.2 million tonnes per year [8,9]. Cauliflower (Brassica oleracea var. botrytis) belongs to the Brassica family. The consumption of the edible part of these vegetables has increased in recent years. This increase can be attributed to the greater interest by European consumers in consuming healthier diets. Specifically, the interest in this vegetable is that it contains a high content of fiber, minerals, vitamins, and can be considered as an excellent source of bioactive compounds that have high antioxidant activity (carotenoids, fatty acids, phenolic compounds, glucosinolates, and polyamines) [10-12]. Due to the wide range of phytochemicals that cauliflower contains, it may be used as preventive treatment in order to protect against many diseases, such as various types of cancers, cardiovascular disease, obesity, type II diabetes, dementia, and immune dysfunction $[10,12,13]$. However, the edible parts only include the inflorescence, while a larger quantity of non-edible proportion is generated. So, over $70 \%$ of this vegetable is constituted by leaves and stems. In this sense, the rise of consumption of cauliflower entails the generation of a large amount of waste each year. During its processing, a large quantity of waste is produced, the leaves constituting around $50 \%$ of the total by-product. This waste is a major problem, as it causes significant environmental effects. Therefore, in recent years, sustainable ways to reuse cauliflower waste have been studied [14,15].

In this sense, some studies have suggested that these by-products could be used as bioingredients in functional foods or as nutraceuticals. This is due to the fact that fruit and vegetable by-products including cauliflower waste could be considered as a good source of high added-value bioactive compounds. Among these bioactive compounds can be highlighted the presence of phenolic compounds and polyamines [15-17].

The polyamines are a group of low-molecular-weight nitrogen metabolites found in all living organisms [18]. These aliphatic amines affect the plant cell activity, and as a consequence they are involved in a wide range of biological processes that include both plant growth and development [18]. Although the mechanisms involved are still not well understood, it is known that these compounds are involved in the responses of plants to various types of abiotic stress, including heat stress [19]. In fact, several studies $[5,20]$ reported that higher levels of free and bound polyamines in plants were obtained as consequence of the exposure of plants to heat stress. Moreover, recent studies have suggested that polyamines can be used in order to enhance the tolerance to heat stress, allowing to obtain a higher total production yield and higher quality of the final plant products $[19,21]$. In nature, polyamines are often found as free molecules, but they can also be found in conjugated or bound forms. Conjugated polyamines result when polyamines are linked to small molecules, such as phenolic acids, whereas when polyamines are linked to macromolecules, such as proteins, they are considered as bound polyamines. These links are due to the polycationic nature of polyamines at physiological $\mathrm{pH}$. Thus, through this property, polyamines can bind to various negatively-charged sites such as those of membrane phospholipids, pectic polysaccharides, proteins, and DNA, thus being able to mediate their biological activity [22].

Among all polyamines, putrescine deserves to be highlighted, since it has been indicated that the exogenous treatment with this polyamine can promote the biosynthesis and/or accumulation of quite bioactive compounds affecting positively in the growth and development of plants. This takes place not only in inflorescence, but also in leaves of different plants. This can lead to both cauliflower more attractive by consumers and by-products cauliflower with add-value, which can allow give an additional valorization 
to that non-edible part of cauliflower with nutraceutical purposes $[15,21]$. In addition, putrescine is the precursor of other polyamines with a higher molecular weight or more nitrogen atoms in their structure, such as spermidine and spermine [21-25].

On the other hand, it is known that usually the plants are supplied with $\mathrm{N}$ in order to favor the development of the plants and to achieve a good vegetable crop production. However, caution is necessary with its use, as excessive amounts of nitrogen can have implications for human health [26]. Previous studies have reported that the form of nitrogen may be more important than the amount of total nitrogen. In fact, this has been reflected in significant effects both on the total crop production and on the quality of the final fruits and vegetables [27]. Thus, a possible solution in order to improve both the plant quality and obtaining an improved number of bioactive compounds can be vary the nutritional solution. Regarding the response of that modulation on the heat stress, some previous studies have shown that the application of $\mathrm{NO}_{3}{ }^{-} / \mathrm{NH}_{4}{ }^{+}$in adequate proportions can alleviate oxidative stress caused by heat stress [21,27]. Moreover, Munene in a study carried out with amaranth species [28] indicated that a high exposure of plants to $\mathrm{NH}_{4}{ }^{+}$can be reflected in a higher accumulation of all polyamines, including putrescine, cadaverine, spermidine, and spermine.

Therefore, the aim of this work was to study how to improve the resistance to heat stress of cauliflower by using of a modification of nutritive solution and the foliar application of putrescine before a short-term heat stress. Additionally, in this study also was evaluated the possibility of taking advantage of the effect of modification of nutritive solution and the foliar application of putrescine before a short-term heat stress on the cauliflower by-product quality in order to obtain cauliflower by-products with added-value for their possible use as preparations for improving human health.

For this, the effect of the exogenous application of putrescine to cauliflower leaves was studied, as well as the effects of heat and exposure to different proportions of $\mathrm{NO}_{3}{ }^{-} / \mathrm{NH}_{4}{ }^{+}$ in both old and young leaves, to evaluate any differences in the responses due to leaf age.

\section{Material and Methods}

\subsection{Experimental Conditions, Plant Material and Treatments}

To carry out this study, plants of the cauliflower cv. Moonshine (Enza Zaden España S.L., Almería, Spain) were used. The seeds were germinated using a mixture of peat and perlite and, after 30 days, seedlings with a similar size were selected and transplanted into 5-L black pots with coconut fiber (Pelemix, Alhama de Murcia, Spain). Previously to transplant, these pots were washed by applying $2 \mathrm{~L}$ of tap water. The nutrient solutions used in the experiment were applied by self-compensating drippers $\left(2 \mathrm{~L} \mathrm{~h}^{-1}\right)$. The drainage was evaluated daily in order to guarantee drainage superior to $35 \%$. In order to evaluate the thermotolerance of the plants as a function of the applied nitrogen $(\mathrm{N})$ source and the application of putrescine, the experiments were carried out in a climatic chamber designed by del Amor et al. [29], with fully-controlled environmental conditions: $60 \%$ relative humidity, $16 / 8 \mathrm{~h}$ day /night with $28 / 16{ }^{\circ} \mathrm{C}$ at first and $43 / 30{ }^{\circ} \mathrm{C}$ during the heat stress and an ambient $\mathrm{CO}_{2}$ concentration of $400 \mu \mathrm{mol} \mathrm{mol}^{-1} \mathrm{CO}_{2}$. The photosynthetically active radiation (PAR) of $250 \mu \mathrm{mol} \mathrm{m}{ }^{-2} \mathrm{~s}^{-1}$ was provided by a combination of fluorescent lamps (TL-D Master reflex 830 and 840, Koninklijke Philips Electronics N.V., The Netherlands) and high-pressure lamps (Son-T Agro, Philips).

The $\mathrm{N}$ treatments consisted of three solutions with different proportions of $\mathrm{NO}_{3}{ }^{-} / \mathrm{NH}_{4}{ }^{+}$ $(100 / 0,80 / 20$, and 50/50). Twenty plants per treatment were used. The experiment started under the initial thermal conditions and on day 86 half of the plants, which were randomly selected, received a foliar spraying with a solution containing $2.5 \mathrm{mM}$ putrescine plus $0.01 \%$ Tween-20 as a surfactant. Each plant was fully sprayed with $20 \mathrm{~mL}$ of the putrescine solution, using a hand sprayer. The putrescine treatment was allowed to act for four days and then half of the sprayed plants and half of the non-sprayed plants were harvested. The plants remaining in the climatic chamber were then exposed to a heat stress at $43 / 30^{\circ} \mathrm{C}$ 
day/night for three days. After that, they were harvested. The experiment ended 93 days after transplantation.

\subsection{Chemicals and Reagents}

Sodium hydroxide and SPE cartridges (C18 Sep-Pak cartridges) were acquired from Fluka (Buchs, Switzerland) and Waters Associates (Milford, Mass.), respectively. Sugars (glucose, sucrose, fructose, and inositol), polyamines (spermidine, spermine, cadaverine, histamine, putrescine and 1,6-hexaendiamine), gallic acid, 6-hydroxy-2,5,7,8-tetramethylchroman2-carboxylic acid (Trolox), 2,2-azino-bis(3-ethylbenzothiazoline-6-sulphonic acid) diammonium salt $\left(\mathrm{ABTS}^{\bullet+}\right.$ ) and benzoyl chloride were purchased from Sigma-Aldrich (Steinheim, Germany). Methanol, acetonitrile (LC-MS grade), sodium carbonate, Folin-Ciocalteu reagent and ethyl ether were obtained from Panreac Química (Barcelona, Spain). Ultrapure water was produced using a Millipore water purification system.

\subsection{Growth and Shoot and Leaf Weights}

The height of the cauliflower plants was determined weekly. The shoot and leaf weights were determined on the same days and for the same plants where the photosynthetic parameters had previously been measured. For the determination of the shoot and leaf weights, intact plants were placed in a collection tray with the shoot and roots in separate compartments. After weighing the whole shoot, the outer and young leaves were separated and weighed.

\subsection{Determination of the Total Phenolic Compounds and Antioxidant Activity $\left(A B T S^{\bullet+}\right)$}

The determination of the total phenolic compounds (TPC) and antioxidant activity was performed in both young and outer cauliflower leaves. The determination of phenolic compounds from fresh leaves was carried out using the Folin-Ciocâlteu colorimetric method [30]. For this, a $0.5 \mathrm{~g}$ sample was homogenized with $5 \mathrm{~mL}$ of extractant (acetone, $80 \%$ ) and centrifuged at $10,000 \times g$, at $4{ }^{\circ} \mathrm{C}$, for $10 \mathrm{~min}$. Later, $100 \mu \mathrm{L}$ of the supernatant were mixed with $1 \mathrm{~mL}$ of Folin-Ciocâlteu reagent (diluted with Milli-Q water, 1:10) and $2 \mathrm{~mL}$ of Milli-Q water. This mixture was incubated at room temperature for $3 \mathrm{~min}$ and then $5 \mathrm{~mL}$ of $20 \%$ sodium carbonate were added, followed by a re-incubation in the dark at room temperature for $1 \mathrm{~h}$. Then, the absorbance of the blue-colored mixture was measured at $765 \mathrm{~nm}$ using a UV-visible spectrophotometer (Shimadzu UV-1800 model with the CPS-240 cell holder, Shimadzu Europa GmbH, Duisburg, Germany). The results were calculated according to a calibration curve of gallic acid and were expressed as gallic acid equivalents (GAE), $\mu \mathrm{g} \mathrm{GAE} \mathrm{g}^{-1}$. For all treatment combinations, five replicates were analysed.

The antioxidant activity was measured in freeze-dried young and outer cauliflower leaves using the $\mathrm{ABTS}^{\bullet+}$ radical, as previously reported [31]. The method of extraction consisted of mixing $0.5 \mathrm{~g}$ of sample with $10 \mathrm{~mL}$ of extractant $(\mathrm{MeOH} /$ water $(80: 20, v / v)+$ $1 \% \mathrm{HCl}$ ) at room temperature, followed by sonication for $15 \mathrm{~min}$ and storage for $24 \mathrm{~h}$ at $4{ }^{\circ} \mathrm{C}$. The resultant extract was sonicated for $15 \mathrm{~min}$ and centrifuged for $10 \mathrm{~min}$ at $10,000 \times \mathrm{g}$. A $10 \mu \mathrm{L}$ sample of the supernatant was mixed with $990 \mu \mathrm{L}$ of the $\mathrm{ABTS}^{\bullet+}(2,2$-azinobis(3-ethylbenzothiazoline-6-sulphonic acid)) radical cation solution, shaken and placed in darkness for $10 \mathrm{~min}$. Then, the absorbance was measured at a wavelength of $734 \mathrm{~nm}$ using a UV-visible spectrophotometer (Shimadzu CPS-240 model, Kyoto, Japan). The antioxidant activity was quantified according to a Trolox calibration curve $\left(0.01-3 \mathrm{mmol}\right.$ Trolox $\left.\mathrm{L}^{-1}\right)$ and expressed in $\mu \mathrm{mol}$ Trolox $\mathrm{g}^{-1}$.

\subsection{Extraction and Quantification of Total Soluble Sugars}

Soluble sugars were extracted as described by Balibrea et al. [32], with some modifications. Briefly, $50 \mathrm{mg}$ of lyophilized young and outer leaves were incubated twice with $1.5 \mathrm{~mL}$ of $80 \%$ methanol $(v / v)$, at $4{ }^{\circ} \mathrm{C}$, for 30 min each time. After centrifugation for 15 min at $3500 \times g$, at $4{ }^{\circ} \mathrm{C}$, each supernatant was filtered through a C18 Sep-Pak cartridge (Waters Associates, Milford, MA), which had been activated previously with $20 \mathrm{~mL}$ of 
methanol/water $(80 \% / 20 \%)$. The two supernatants were combined and filtered through a $0.45 \mu \mathrm{m}$ filter (Millipore, Beford, MA, USA). The concentrations of inositol, glucose, fructose, and sucrose in the extracts were determined directly by ion chromatography with an 817 Bioscan (Metrohm, Herisau, Switzerland) system equipped with a pulsed amperometric detector (PAD) and a gold electrode, using a METROHM Metrosep Carb 1-150 IC column $(4.6 \times 250 \mathrm{~mm})$, which was heated to $32{ }^{\circ} \mathrm{C}$.

\subsection{Extraction of Polyamines and Their Analysis by UHPLC}

Polyamines from $5 \mathrm{~g}$ of fresh young and outer leaves were extracted by homogenization with $1.2 \mathrm{~mL}$ of $5 \%(v / v)$ cold $\mathrm{HClO}_{4}$ for $1 \mathrm{~min}$, using an ultraturrax (Ika, Staufen, Germany). The extract was centrifuged (Eppendorf centrifuge 5804R, Hamburg, Germany) at $12,000 \times \mathrm{g}$ for $8 \mathrm{~min}$, at $4^{\circ} \mathrm{C}$. The supernatants were derivatized with benzoyl chloride, using a slight modification of the technique used by Rodríguez et al. [33]. An aliquot of $500 \mu \mathrm{L}$ of supernatant was mixed with $2 \mathrm{~mL}$ of $2 \mathrm{M} \mathrm{NaOH}$ and $20 \mu \mathrm{L}$ of benzoyl chloride; this mixture was vortexed for $15 \mathrm{~s}$ and incubated for $20 \mathrm{~min}$ at room temperature. Then, $4 \mathrm{~mL}$ of a saturated $\mathrm{NaCl}$ solution were added in order to stop the reaction and the polyamines were extracted with $4 \mathrm{~mL}$ of cold diethyl ether. Both resulting phases (aqueous and organic) were stored at $-20{ }^{\circ} \mathrm{C}$ until the extraction of the total polyamines in the ether phase had been achieved. From the resulting upper phase, $1.5 \mathrm{~mL}$ were evaporated by a SpeedVac Evaporator (Savant SPD121P, Thermo Scientific, Waltham, MA, USA). The resulting sample was dissolved in $500 \mu \mathrm{L}$ of the mobile phase (water/acetonitrile, 58/42\%, $v / v$ ). Standards of polyamines were treated in a similar way. Aliquots of $10 \mu \mathrm{L}$ were injected into a UHPLC-DAD (Waters, Milford, USA). To obtain a satisfactory chromatographic separation, an ACQUITY UPLC HSS T3 column $(2.1 \times 100 \mathrm{~mm}, 1.8 \mu \mathrm{m})$ (Waters Corp., Wexford, Ireland) was used with only one eluent: water plus acetonitrile $(58 / 42 \%, v / v)$. The elution was performed at a flow rate of $0.55 \mathrm{~mL} \mathrm{~min}^{-1}$ and the column temperature was kept at $40{ }^{\circ} \mathrm{C}$. Data acquisition and processing were performed using Empower 2 (Waters) software. Polyamine peaks were detected at $254 \mathrm{~nm}$. Five replicates per treatment were analysed.

\subsection{Statistical Analysis}

The experiment had a completely randomized design with a $3 \times 2 \times 2$ factorial arrangement composed of three nitrogen sources ratio (control (100:0), 80:20 and 50:50), two putrescine application (absence and presence of putrescine at $2.5 \mathrm{mM}$ ), and two temperature levels $\left(28^{\circ} \mathrm{C}\right.$ and $\left.43^{\circ} \mathrm{C}\right)$. Analysis were performed six repetition per treatment (and individual plant per plot was considered one repetition). The data was tested first for homogeneity of variance and normality of distribution. To check the regression model hypothesis (linearity, homoscedasticity, normality, and independency), the KolmogorovSmirnov test was used with the Liliefors correction and the Shapiro-Wilk test for normality and the Levene test for homoscedasticity on the typified residuals. An analysis of variance (ANOVA) was performed, considering the different treatments, when the data were in accordance with the assumptions of normality and homogeneity of variance. To determine differences among the mean values, a post hoc Tukey's test $(p \leq 0.05)$ in SPSS v.21 (IBM, Chicago, IL, USA) was conducted. Values for each replicate were averaged before the mean and standard error (SE) of each treatment were calculated. Combinations of treatments were used-involving three $\mathrm{NO}_{3}{ }^{-} / \mathrm{NH}_{4}{ }^{+}$ratios (control (100:0), 80:20 and 50:50), two temperatures $\left(28^{\circ} \mathrm{C}\right.$ and $43^{\circ} \mathrm{C}$ ) and the presence/absence of $2.5 \mathrm{mM}$ putrescine-with five plants per combination.

\section{Results and Discussion}

\subsection{Analysis of Biomass}

Under heat stress, and with increased $\mathrm{NH}_{4}{ }^{+}$in the nutrient solution, the cauliflower plants had greater biomass than in control conditions (Figure 1A-D). A similar trend was found by other authors for plants exposed to several abiotic stresses and a nutrient solution 
enriched with $\mathrm{NH}_{4}{ }^{+}$[34-37]. Previous work has shown higher tolerance of abiotic stresses in different plant species according to the $\mathrm{NO}_{3}{ }^{-} / \mathrm{NH}_{4}{ }^{+}$ratio [34]. Some studies claimed that the foliar application of putrescine at an adequate concentration, as in our case, can give rise to a series of physiological processes in the plant and generate the biosynthesis of bioactive compounds, some of them being osmoprotective. This response is in order to alleviate/compensate the negative effects on the plant biomass of the abiotic stress. In this way, the foliar application of putrescine can give rise not only to a plant of higher quality, but also a healthier plant [38]. Of note is the fact that the metabolism of polyamines is related not only to the generation of reactive oxygen species, but also the production of nitric oxide. This gaseous molecule not only acts as an intra- and intercellular messenger, but also as an intermediate signalling molecule for plant growth [39]. Yang et al., [40] reported that exogenous application of putrescine induced nitric oxide generation in soybean. This could be a consequence of the fact that polyamines can modulate the arginine-linked nitric acid synthase and nitrate reductase pathways [38]. Thus, according to several authors, this positions this molecule as an intermediary involved in various physiological effects and the mitigation of stress [38].

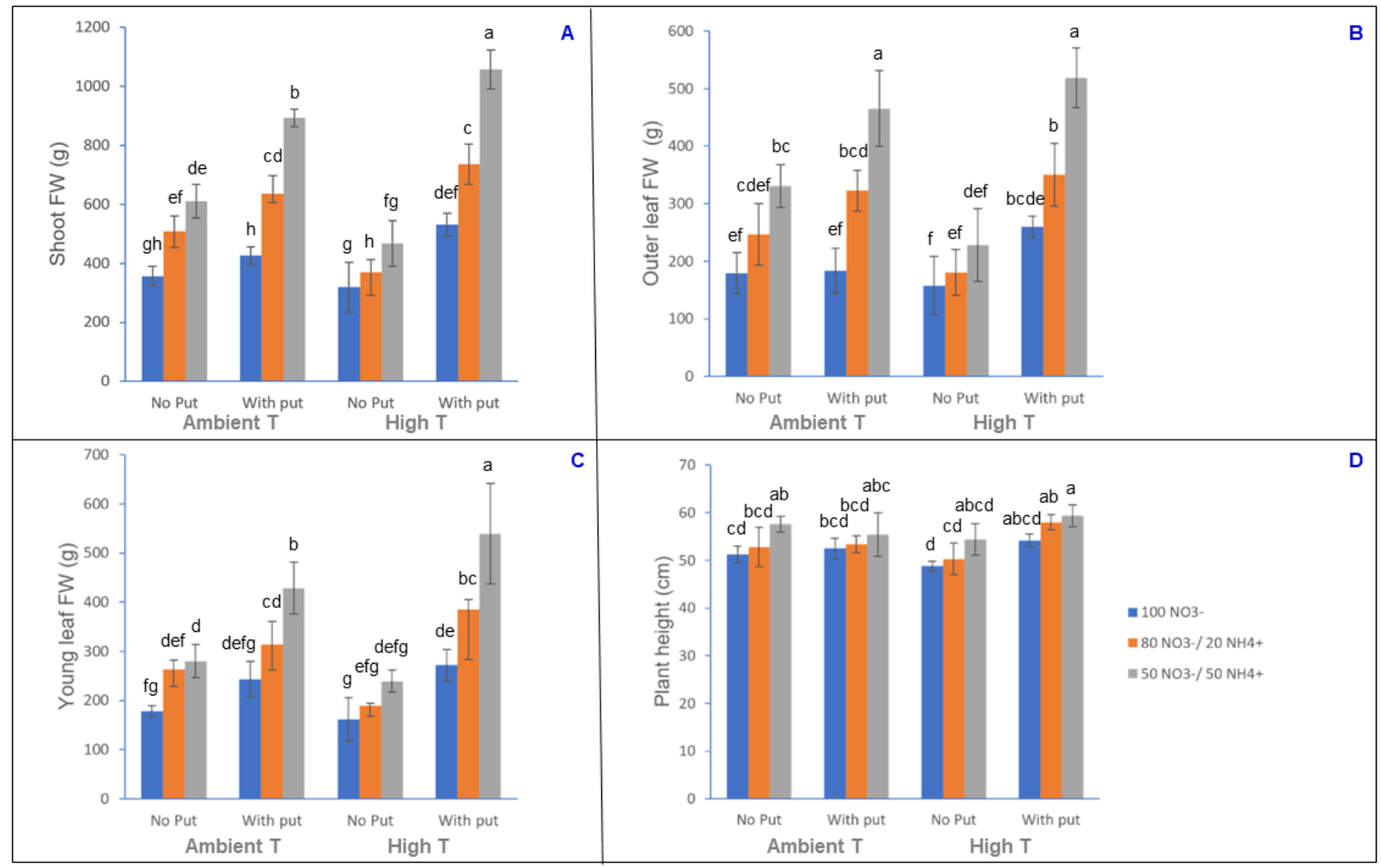

Figure 1. Effect of heat stress, different $\mathrm{NO}_{3}{ }^{-} / \mathrm{NH}_{4}{ }^{+}$ratios and the foliar application of $2.5 \mathrm{mM}$ putrescine on shoot $\mathrm{FW}$ (A), outer leaf FW (B), young leaf FW (C), and plant height (D) of cauliflower. For data analysis, an ANOVA was performed and the pairwise changes were defined using the Tukey post hoc test. Thus, different letters represent significantly different mean values according to the Tukey test at $p \leq 0.05$.

\subsection{Evaluation of the Antioxidant Activity and Total Phenolic Compounds}

The extracts from cauliflower waste seem to be a good source of TPC and they showed good scavenging activity against $\mathrm{ABTS}^{\bullet+}$ radicals. Our results show that TPC content varied from $80.5 \mu \mathrm{g} \mathrm{GAE} \mathrm{g}^{-1} \mathrm{FW}$, in the outer leaves under the control treatment, to $574.8 \mu \mathrm{g} \mathrm{GAE} \mathrm{g}^{-1} \mathrm{FW}$, in the younger leaves of plants subjected to a short heat shock and grown with a 50:50 $\mathrm{NO}_{3}{ }^{-} / \mathrm{NH}_{4}{ }^{+}$ratio (Figure 2). Taking into consideration that in our experiment the moisture content of the cauliflower leaves varied between $9 \%$ (in younger leaves subjected to heat stress, a 50:50 $\mathrm{NO}_{3}{ }^{-} / \mathrm{NH}_{4}{ }^{+}$ratio and putrescine 
application) and 30\% (in outer leaves in the control treatment) (data not shown), the TPC content ranged between $268.33 \mu \mathrm{g} \mathrm{GAE} \mathrm{g}{ }^{-1} \mathrm{DW}$ and $6386.7 \mu \mathrm{g} \mathrm{GAE} \mathrm{g}{ }^{-1} \mathrm{DW}$. Although these values are lower than those found in the edible part of the white cauliflower cv. Moonshine [41], they can be considered to be in accordance with the TPC concentrations reported by other authors for cauliflower waste: between $4855.8 \mu \mathrm{g} \mathrm{GAE} \mathrm{g}^{-1} \mathrm{DW}$ and $6109 \mu \mathrm{g} \mathrm{GAE} \mathrm{g}^{-1} \mathrm{DW}$ [42]. Figure 2 shows that the outer and young leaves had antioxidant activity values between 49.00 and $332.6 \mu \mathrm{mol}$ Trolox $\mathrm{g}^{-1} \mathrm{DW}$, in agreement with those found by other authors for extracts of raw cauliflower by-products [15] and intermediate in comparison with other leafy species of the Brassicaceae [43]. Some previous works have attributed such high antioxidant activity not only to phenolic compounds, but also to substances such as soluble fiber, glucosinolates, and their derived products, such as isothiocyanates, that are present in cauliflower waste and have potent anticancer effects [15].

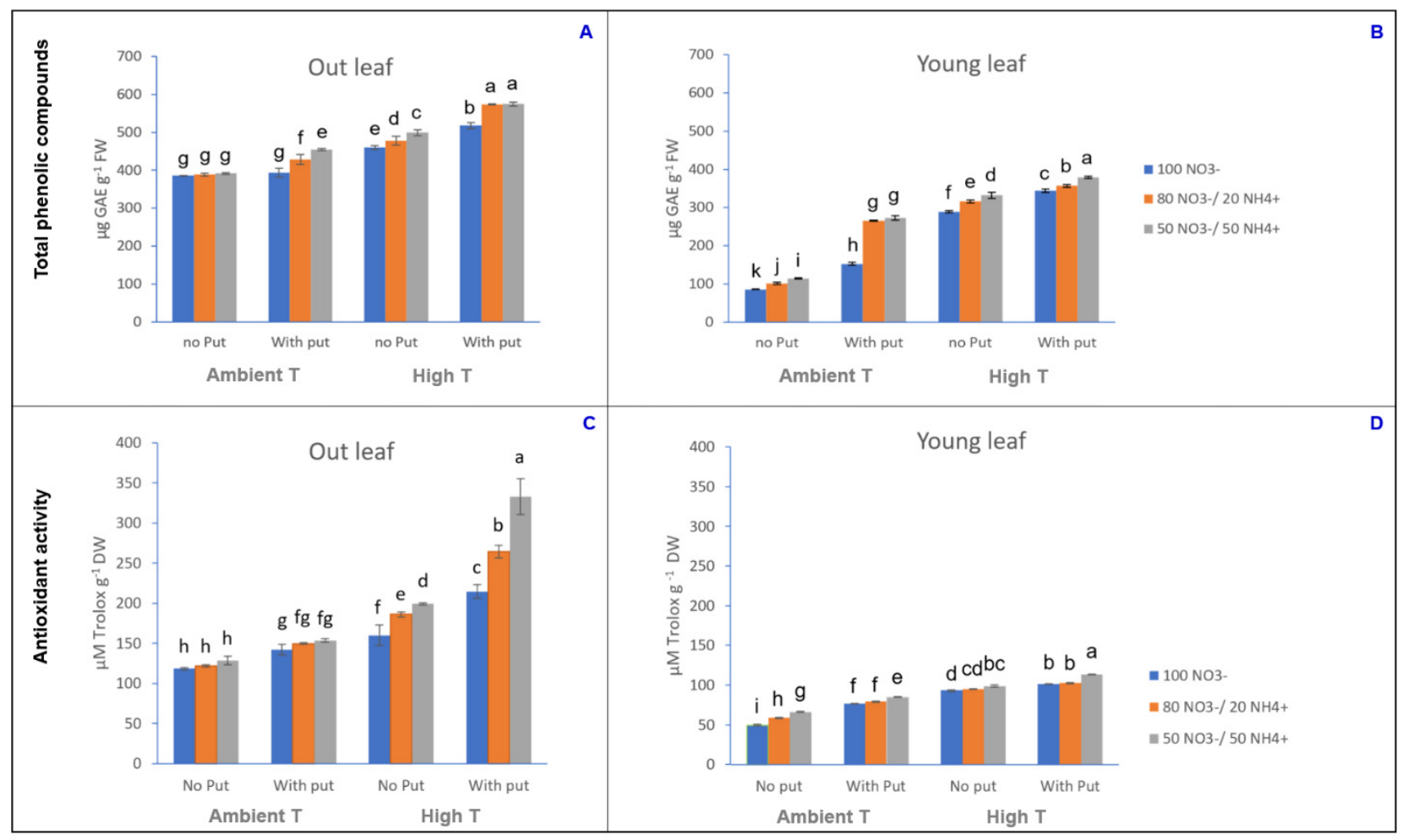

Figure 2. Total phenolic compounds in outer and young leaves (A,B), respectively and antioxidant activity in outer and young leaves (C,D), respectively of the cauliflower cv. Moonshine. For data analysis, an ANOVA was performed and the pairwise changes were defined using the Tukey post hoc test. Thus, different letters represent significantly different mean values according to the Tukey test at $p \leq 0.05$.

Although other authors have reported the possibility of using cauliflower residues from various points of view [14,15], this is the first work where their beneficial properties have been studied in order to be improved with regard to the pharmaceutical, cosmetics, and food industries. It is known that thermal stress is accompanied by an increase in the concentration of reactive oxygen species [4]. In this study, the short-term heat stress had a significant impact on the TPC and antioxidant activity of cauliflower leaves (Figure 2, Table 1, Table S1). This increase in TPC and antioxidant activity can be ascribed to a higher PAL (phenylalanine ammonia-lyase) activity resulting from thermal stress, since PAL is considered one of the main lines of cell acclimation against stress in plants [44]. 
Table 1. Explanation statistical of the data exhibited in Figure 2.

\begin{tabular}{|c|c|c|c|c|}
\hline \multirow[t]{2}{*}{ Main Effects } & \multicolumn{2}{|c|}{ Total Phenolic Compounds } & \multicolumn{2}{|c|}{ Antioxidant Activity } \\
\hline & Outer leaves & Young leaves & Outer leaves & Young leaves \\
\hline $\mathrm{T}$ & $* * *$ & $* * *$ & $* * *$ & $* * *$ \\
\hline Put & $* * *$ & $* * *$ & $* * *$ & $* * *$ \\
\hline $\mathrm{NO}_{3}{ }^{-} / \mathrm{NH}_{4}{ }^{+}$ & $* * *$ & $* * *$ & $* * *$ & $* * *$ \\
\hline TX Put & ns & ns & $* * *$ & $*$ \\
\hline $\mathrm{T} \times \mathrm{NO}_{3}{ }^{-} / \mathrm{NH}_{4}^{+}$ & $* * *$ & $* *$ & $* * *$ & ns \\
\hline Put $X \mathrm{NO}_{3}^{-} / \mathrm{NH}_{4}^{+}$ & $* * *$ & $* * *$ & $* * *$ & $* * *$ \\
\hline $\mathrm{T} X$ Put $X \mathrm{NO}_{3}{ }^{-} / \mathrm{NH}_{4}{ }^{+}$ & $* * *$ & $* * *$ & $* * *$ & $* * *$ \\
\hline
\end{tabular}

The effect of heat stress, different $\mathrm{NO}_{3}{ }^{-} / \mathrm{NH}_{4}{ }^{+}$ratios and the foliar application of $2.5 \mathrm{mM}$ putrescine. The data are presented as the treatment means $(n=5)$. Different letters represent significantly different mean values according to the Tukey test at $p \leq 0.05$. Analysis of variance: $\mathrm{ns}$, not significant; $p \leq 0.05 ;{ }^{* *} p \leq 0.005 ;{ }^{* * *} p \leq 0.001$.

The nutrient solution $\mathrm{NO}_{3}{ }^{-} / \mathrm{NH}_{4}{ }^{+}$ratio also had a significant effect on the TPC and antioxidant activity of cauliflower leaves (Figure 2). It is known that $\mathrm{N}$ fertilization practices have an important influence on the biosynthesis of phenolic compounds. In fact, previous findings showed that the total phenolics content is significantly increased in N-starved plants. This indicates that the biosynthesis of secondary plant metabolites is stimulated by a lower availability of $\mathrm{N}$, inducing a plant defense mechanism against nutritional stress. It can be ascribed to the fact that the accumulation of excess carbon in plants in response to nutrient stress leads to higher production of secondary carbon-based metabolites. In line with this hypothesis, a study carried out with Carica papaya revealed that phenolic compounds act as primary antioxidants [28]. In several studies, plants exposed to a high concentration of $\mathrm{NH}_{4}{ }^{+}$showed a high accumulation of polyamines, which act as precursors of some secondary metabolites, alleviating the stress [28].

The phenolic compounds and antioxidant activity in cauliflower leaves were increased as a result of the exogenous application of putrescine, as well. This is in agreement with Chen and collaborators [38], who indicated that polyamines promote not only photosynthetic activity, but also the antioxidant capacity and osmotic adjustment ability of plants. In particular, in work carried out in wheat, foliar treatment with putrescine $(2.5 \mathrm{mM})$ alleviated the adverse effect of high temperature, increasing the thermotolerance [45]. As can be seen in Figure 2, in the present study, the distribution of phenolic compounds varied as a consequence of the application of thermal and nutritional stresses, and the content of phenolic compounds also varied with the age of the leaves. In this sense, our data show that the young leaves from stressed plants had a greater accumulation of TPC than the outer leaves. This finding is in accordance with several studies performed in many higher plant species during the last two decades, which stated that young tissues generally have higher accumulation of secondary metabolites overall in plants that suffer any abiotic stress [44].

\subsection{Determination of Sugars}

The chromatographic profile of the sugars in the cauliflower leaves was constituted by four free sugars (inositol, glucose, fructose, and sucrose). These sugars were determined by comparison of their retention times with those of commercial standards. As can be seen in Table 2 (and Table S2) the total sugars content oscillated between 159.57 and $251.20 \mathrm{mg}$ $\mathrm{kg}^{-1} \mathrm{DW}$ for younger leaves, and for outer leaves between 241.04 and $313.99 \mathrm{mg} \mathrm{kg}^{-1} \mathrm{DW}$. In the case of the individual free sugars, glucose exhibited the highest content $(p \leq 0.05)$, whilst sucrose was the least abundant. The levels of total free sugars in the freeze-dried cauliflower leaves in the current work were higher than those found by Bhandari and Kwak [42], who reported values of 192.0, 214.8, and $224.4 \mathrm{mg} \mathrm{g}^{-1}$ for cauliflower leaves, depending on the cultivar. As expected, due to their role as osmoprotective metabolites, the content of these free sugars was positively influenced by the short heat stress $[46,47]$. This may be ascribed to inhibition of sucrose synthase or invertase activity, so that during stress sucrose is cleaved into fructose and glucose [46,47]. A similar response to heat 
stress, to achieve an adequate osmotic adjustment, was obtained when the effect of the nutrient solution $\mathrm{NO}_{3}{ }^{-} / \mathrm{NH}_{4}{ }^{+}$ratio on the sugars content was studied. Thus, the results displayed in Table 3 (and Table S3) show that the sugar concentration in cauliflower leaves was positively influenced by an increase in the proportion of $\mathrm{NH}_{4}{ }^{+}$to $20 \%$ or $50 \%$ in the nutrient solution. These results are consistent with those obtained previously, where it was observed that those plants nourished with higher proportions of $\mathrm{NH}_{4}{ }^{+}$could exhibit higher energy efficiency [27]. Of note is the fact that, in our study, the increase in the total sugars content was more pronounced when the $\mathrm{NO}_{3}{ }^{-} / \mathrm{NH}_{4}{ }^{+}$ratio supplied to plants subjected to high temperatures was altered. The highest and lowest concentration of sucrose and fructose, respectively, was observed in plants grown with the $50: 50 \mathrm{NO}_{3}{ }^{-} / \mathrm{NH}_{4}{ }^{+}$ratio, while the highest concentration of glucose was observed with the $80: 20 \mathrm{NO}_{3}{ }^{-} / \mathrm{NH}_{4}{ }^{+}$ratio. These findings are in accordance with those reported by Petropoulos et al. [27], who found that an increase in sucrose at a $\mathrm{NO}_{3}{ }^{-} / \mathrm{NH}_{4}{ }^{+}$ratio of 50:50 may have been due more to fructose than to glucose.

Tables 2 and 3 show that the spraying of the cauliflower leaves with putrescine increased the accumulation of sugars. This may be due to the counteracting of increased reactive oxygen species levels by the sprayed polyamine and, in turn, to the direct correlation that exists between the reactive oxygen species present in the cells and the sugars accumulated. So, in addition to acting as osmoprotective metabolites, sugars could act as reactive oxygen species scavengers and help to achieve membrane stabilization under abiotic stress [39]. Thus, our results suggest that the effect of putrescine $(2.5 \mathrm{mM})$ foliar treatments on cauliflower plants may be related to their thermotolerance through enhanced osmoregulation.

Table 2. Effect of the foliar application of putrescine on the concentrations of sugars $\left(\mathrm{g} \mathrm{kg}^{-1} \mathrm{DW}\right)$ in outer leaves of the cauliflower cv. Moonshine at different $\mathrm{NO}_{3}{ }^{-} / \mathrm{NH}_{4}{ }^{+}$ratios and temperatures.

\begin{tabular}{|c|c|c|c|c|c|c|c|}
\hline Temperature & $\mathrm{NO}_{3}{ }^{-} / \mathrm{NH}_{4}{ }^{+}$ & & Inositol & Glucose & Fructose & Sucrose & $\begin{array}{c}\text { Total Free } \\
\text { Sugars }\end{array}$ \\
\hline \multirow{6}{*}{$\begin{array}{c}\text { Ambient } \\
\text { temperature }\end{array}$} & \multirow{2}{*}{$100 / 0$} & Without Put & $5.50 \mathrm{~h}$ & $39.71 \mathrm{~g}$ & $12.91 \mathrm{~g}$ & $101.43 \mathrm{f}$ & $159.57 \mathrm{c}$ \\
\hline & & With Put & $11.04 \mathrm{f}$ & $71.12 \mathrm{e}$ & $18.34 \mathrm{e}$ & $108.03 \mathrm{e}$ & $208.54 \mathrm{~b}$ \\
\hline & \multirow{2}{*}{$80 / 20$} & Without Put & $8.08 \mathrm{~g}$ & $75.80 \mathrm{e}$ & $11.31 \mathrm{~h}$ & $114.33 \mathrm{~d}$ & $209.53 \mathrm{ab}$ \\
\hline & & With Put & $12.38 \mathrm{f}$ & $85.41 \mathrm{~cd}$ & $15.84 \mathrm{f}$ & $123.22 \mathrm{c}$ & $236.86 \mathrm{a}$ \\
\hline & \multirow{2}{*}{$50 / 50$} & Without Put & $8.75 \mathrm{~g}$ & $60.47 \mathrm{f}$ & $9.25 \mathrm{i}$ & $142.90 \mathrm{~b}$ & $221.38 \mathrm{ab}$ \\
\hline & & With Put & $15.02 \mathrm{e}$ & 83.08 de & $13.84 \mathrm{~g}$ & $149.75 \mathrm{a}$ & $261.70 \mathrm{a}$ \\
\hline \multirow{6}{*}{ High temperature } & \multirow{2}{*}{$100 / 0$} & Without Put & $18.69 \mathrm{~d}$ & $97.25 \mathrm{bc}$ & $25.49 \mathrm{~b}$ & $72.78 \mathrm{j}$ & $214.22 \mathrm{ab}$ \\
\hline & & With Put & $21.80 \mathrm{c}$ & $101.32 \mathrm{ab}$ & $28.14 \mathrm{a}$ & $82.37 \mathrm{i}$ & $233.64 \mathrm{a}$ \\
\hline & \multirow{2}{*}{$80 / 20$} & Without Put & $20.34 \mathrm{~cd}$ & $105.92 \mathrm{a}$ & $23.49 c$ & $76.35 \mathrm{j}$ & $226.12 \mathrm{ab}$ \\
\hline & & With Put & $23.37 \mathrm{~b}$ & $112.18 \mathrm{a}$ & $27.76 \mathrm{a}$ & $88.39 \mathrm{~h}$ & $251.71 \mathrm{a}$ \\
\hline & \multirow{2}{*}{$50 / 50$} & Without Put & $21.46 c$ & $93.97 \mathrm{bc}$ & $21.06 \mathrm{~d}$ & $95.29 \mathrm{~g}$ & $231.79 \mathrm{ab}$ \\
\hline & & With Put & $25.34 \mathrm{a}$ & $99.71 \mathrm{ab}$ & $27.38 \mathrm{a}$ & $98.75 \mathrm{fg}$ & $251.20 \mathrm{a}$ \\
\hline \multicolumn{8}{|l|}{ Main effects } \\
\hline Temperature (T) & & & $* * *$ & $* * *$ & $* * *$ & $* * *$ & $* * *$ \\
\hline Putrescine (Put) & & & $* * *$ & $* * *$ & $* * *$ & $* * *$ & * \\
\hline $\begin{array}{l}\text { Nitrate/ammonium } \\
\left(\mathrm{NO}_{3}-/ \mathrm{NH}_{4}^{+}\right)\end{array}$ & & & $* * *$ & $* * *$ & $* * *$ & $* * *$ & $* * *$ \\
\hline TXPut & & & ns & $* * *$ & ns & ns & $*$ \\
\hline $\mathrm{T} \times \mathrm{NO}_{3}{ }^{-} / \mathrm{NH}_{4}{ }^{+}$ & & & ns & $* * *$ & ns & $* *$ & $* * *$ \\
\hline $\begin{array}{c}\text { Put X } \\
\mathrm{NO}_{3}{ }^{-} / \mathrm{NH}_{4}{ }^{+}\end{array}$ & & & $* * *$ & $* * *$ & $* * *$ & $* * *$ & ns \\
\hline $\begin{array}{c}\text { TX Put X } \\
\mathrm{NO}_{3}^{-} / \mathrm{NH}_{4}^{+}\end{array}$ & & & * & $* * *$ & $* *$ & $* * *$ & $* *$ \\
\hline
\end{tabular}

Different small letters within a column indicate significant differences among the different putrescine treatments, $\mathrm{NO}_{3}{ }^{-} / \mathrm{NH}_{4}{ }^{+}$ratios and temperatures ( $p=0.05$, Tukey test). Analysis of variance: ns, not significant; ${ }^{*} p \leq 0.05 ;{ }^{* *} p \leq 0.005$; ${ }^{* * *} p \leq 0.001$. 
Table 3. Effect of the foliar application of putrescine on the concentrations of sugars $\left(\mathrm{g} \mathrm{kg}^{-1} \mathrm{DW}\right)$ in younger leaves of the cauliflower cv. Moonshine at different $\mathrm{NO}_{3}{ }^{-} / \mathrm{NH}_{4}{ }^{+}$ratios and temperatures.

\begin{tabular}{|c|c|c|c|c|c|c|c|}
\hline Temperature & $\mathrm{NO}_{3}{ }^{-} / \mathrm{NH}_{4}{ }^{+}$ & & Inositol & Glucose & Fructose & Sucrose & $\begin{array}{c}\text { Total free } \\
\text { sugars }\end{array}$ \\
\hline \multirow{6}{*}{$\begin{array}{c}\text { Ambient } \\
\text { temperature }\end{array}$} & \multirow{2}{*}{$100 / 0$} & Without Put & $26.53 \mathrm{i}$ & $117.08 \mathrm{i}$ & $31.75 \mathrm{fg}$ & $65.68 \mathrm{bc}$ & $241.04 \mathrm{~g}$ \\
\hline & & With Put & $30.39 \mathrm{fg}$ & $137.29 \mathrm{fg}$ & $36.12 \mathrm{~cd}$ & $70.81 \mathrm{a}$ & $274.62 \mathrm{e}$ \\
\hline & \multirow{2}{*}{$80 / 20$} & Without Put & $28.07 \mathrm{hi}$ & $128.75 \mathrm{gh}$ & $31.67 \mathrm{fg}$ & $67.43 \mathrm{~b}$ & $256.00 \mathrm{f}$ \\
\hline & & With Put & $31.61 \mathrm{ef}$ & $152.33 \mathrm{e}$ & $34.25 \mathrm{de}$ & $71.49 \mathrm{a}$ & $289.68 \mathrm{bcd}$ \\
\hline & \multirow{2}{*}{$50 / 50$} & Without Put & $28.64 \mathrm{gh}$ & $122.76 \mathrm{hi}$ & $30.47 \mathrm{~h}$ & $69.95 \mathrm{a}$ & $251.82 \mathrm{fg}$ \\
\hline & & With Put & $32.62 \mathrm{de}$ & $143.41 \mathrm{f}$ & 32.67 ef & $72.52 \mathrm{a}$ & 281.22 cde \\
\hline \multirow{6}{*}{ High temperature } & \multirow{2}{*}{$100 / 0$} & Without Put & $34.28 \mathrm{~cd}$ & $153.88 \mathrm{de}$ & $36.98 \mathrm{bc}$ & $51.04 \mathrm{~g}$ & $276.18 \mathrm{de}$ \\
\hline & & With Put & $37.52 \mathrm{~b}$ & 158.78 cde & $40.76 \mathrm{a}$ & $59.36 \mathrm{e}$ & $302.45 \mathrm{~b}$ \\
\hline & \multirow{2}{*}{$80 / 20$} & Without Put & $35.97 \mathrm{bc}$ & $165.02 \mathrm{bc}$ & $36.82 \mathrm{bc}$ & $56.53 \mathrm{f}$ & $292.29 \mathrm{bc}$ \\
\hline & & With Put & $37.30 \mathrm{~b}$ & $175.32 \mathrm{a}$ & $38.83 \mathrm{~b}$ & $61.51 \mathrm{de}$ & $312.99 \mathrm{a}$ \\
\hline & \multirow{2}{*}{$50 / 50$} & Without Put & $37.32 \mathrm{~b}$ & $162.96 \mathrm{~cd}$ & $36.05 \mathrm{~cd}$ & $59.54 \mathrm{e}$ & $291.90 \mathrm{bc}$ \\
\hline & & With Put & $39.82 \mathrm{a}$ & $172.64 \mathrm{ab}$ & $38.14 \mathrm{bc}$ & $63.38 \mathrm{~cd}$ & $313.99 \mathrm{a}$ \\
\hline \multicolumn{8}{|l|}{ Main effects } \\
\hline Temperature (T) & & & $* * *$ & $* * *$ & $* * *$ & $* * *$ & $* * *$ \\
\hline Putrescine (Put) & & & $* * *$ & * & $* *$ & $* * *$ & $* *$ \\
\hline $\begin{array}{l}\text { Nitrate/ammonium } \\
\qquad\left(\mathrm{NO}_{3}{ }^{-} / \mathrm{NH}_{4}{ }^{+}\right)\end{array}$ & & & $* * *$ & $* * *$ & $* * *$ & $* * *$ & $* * *$ \\
\hline TXPut & & & ns & ns & ns & ns & ns \\
\hline $\mathrm{T} \times \mathrm{NO}_{3}{ }^{-} / \mathrm{NH}_{4}{ }^{+}$ & & & ns & ns & ns & $*$ & ns \\
\hline Put $X \mathrm{NO}_{3}^{-} / \mathrm{NH}_{4}{ }^{+}$ & & & $* * *$ & $* * *$ & $* * *$ & $* * *$ & $* * *$ \\
\hline $\begin{array}{c}\text { T X Put X } \\
\mathrm{NO}_{3}{ }^{-} / \mathrm{NH}_{4}{ }^{+}\end{array}$ & & & ns & $*$ & ns & ns & ns \\
\hline
\end{tabular}

Different small letters within a column indicate significant differences among the different putrescine treatments, $\mathrm{NO}_{3}{ }^{-} / \mathrm{NH}_{4}{ }^{+}$ratios and temperatures ( $p=0.05$, Tukey test). Analysis of variance: ns, not significant; ${ }^{*} p \leq 0.05 ;{ }^{* *} p \leq 0.005 ; * * * \leq 0.001$.

As happened with the TPC, the sugars content was higher in young leaves than in outer ones. This finding is in agreement with previous results showing that young leaves have high metabolic rates and a great demand for resources, and thus compete with other organs of the plant [39].

\subsection{Identification and Quantification of Polyamines by UHPLC-DAD}

In this work the cauliflower leaves contained four free polyamines (putrescine, cadaverine, spermidine, and spermine). They were identified and tentatively quantified by taking into account their retention times and by comparison with the peaks of commercial standards. Tables 4 and 5 show that the polyamines contents varied significantly, with values between 20.49 and $63.16 \mathrm{nmols} \mathrm{g}^{-1}$ for outer leaves and between 51.84 and $97.05 \mathrm{nmols} \mathrm{g}^{-1}$ for younger leaves. Putrescine was the most abundant, followed by spermidine, and the least abundant was spermine (Tables 4 and 5). The contents are high with respect to those obtained for leaves of Brassica napus [44]. 
Table 4. Effect of the foliar application of putrescine on the concentrations of polyamines (nmols $\mathrm{g}^{-1}$ ) in outer leaves of the cauliflower cv. Moonshine at different $\mathrm{NO}_{3}{ }^{-} / \mathrm{NH}_{4}{ }^{+}$ratios and temperatures.

\begin{tabular}{|c|c|c|c|c|c|c|c|}
\hline Temperature & $\mathrm{NO}_{3}{ }^{-} / \mathrm{NH}_{4}{ }^{+}$ & & Putrescine & Cadaverine & Spermidine & Spermine & Total \\
\hline \multirow{6}{*}{$\begin{array}{l}\text { Ambient } \\
\text { temperature }\end{array}$} & \multirow{2}{*}{$100 / 0$} & Without Put & $6.30 \mathrm{j}$ & $7.33 \mathrm{j}$ & $4.50 \mathrm{k}$ & $2.37 c$ & $20.49 \mathrm{k}$ \\
\hline & & With Put & $13.74 \mathrm{~g}$ & $9.10 \mathrm{~h}$ & $10.63 \mathrm{~h}$ & $3.22 \mathrm{abc}$ & $36.69 \mathrm{~h}$ \\
\hline & \multirow{2}{*}{$80 / 20$} & Without Put & $8.24 \mathrm{i}$ & $8.49 \mathrm{i}$ & $5.85 \mathrm{j}$ & $2.82 \mathrm{bc}$ & $25.41 \mathrm{j}$ \\
\hline & & With Put & $15.62 \mathrm{f}$ & $10.03 \mathrm{~g}$ & $12.34 \mathrm{~g}$ & $3.07 \mathrm{abc}$ & $41.04 \mathrm{~g}$ \\
\hline & \multirow{2}{*}{$50 / 50$} & Without Put & $11.36 \mathrm{~h}$ & $11.09 \mathrm{f}$ & $8.66 \mathrm{i}$ & $2.93 \mathrm{abc}$ & $34.04 \mathrm{i}$ \\
\hline & & With Put & $16.45 \mathrm{e}$ & $12.37 \mathrm{~d}$ & $13.59 \mathrm{f}$ & $3.31 \mathrm{abc}$ & $45.72 \mathrm{f}$ \\
\hline \multirow{6}{*}{ High temperature } & \multirow{2}{*}{$100 / 0$} & Without Put & $17.21 \mathrm{e}$ & $11.76 \mathrm{e}$ & $14.47 \mathrm{e}$ & $3.37 \mathrm{abc}$ & $46.81 \mathrm{e}$ \\
\hline & & With Put & $21.65 b$ & $14.99 \mathrm{~b}$ & $16.82 \mathrm{c}$ & $3.45 \mathrm{ab}$ & $56.91 \mathrm{c}$ \\
\hline & \multirow{2}{*}{$80 / 20$} & Without Put & $18.14 \mathrm{~d}$ & $13.31 \mathrm{c}$ & $15.55 \mathrm{~d}$ & $3.53 \mathrm{ab}$ & $50.53 \mathrm{~d}$ \\
\hline & & With Put & $22.34 \mathrm{a}$ & $15.29 \mathrm{ab}$ & $19.51 \mathrm{~b}$ & $3.73 \mathrm{ab}$ & $60.87 \mathrm{~b}$ \\
\hline & \multirow{2}{*}{$50 / 50$} & Without Put & $20.76 \mathrm{c}$ & $14.87 \mathrm{~b}$ & $16.14 \mathrm{~cd}$ & $3.60 \mathrm{ab}$ & $55.37 \mathrm{c}$ \\
\hline & & With Put & $22.74 \mathrm{a}$ & $15.63 \mathrm{a}$ & $20.84 \mathrm{a}$ & $3.95 \mathrm{a}$ & $63.16 \mathrm{a}$ \\
\hline \multicolumn{8}{|l|}{ Main effects } \\
\hline Temperature $(\mathrm{T})$ & & & $* * *$ & $* * *$ & $* * *$ & $* * *$ & $* * *$ \\
\hline Putrescine (Put) & & & $* * *$ & $* * *$ & $* * *$ & $*$ & $* * *$ \\
\hline $\begin{array}{l}\text { Nitrate/ammonium } \\
\qquad\left(\mathrm{NO}_{3}{ }^{-} / \mathrm{NH}_{4}{ }^{+}\right)\end{array}$ & & & $* * *$ & $* * *$ & $* * *$ & ns & $* * *$ \\
\hline T X Put & & & $* * *$ & $* * *$ & $*$ & ns & $* * *$ \\
\hline $\mathrm{T} \times \mathrm{NO}_{3}{ }^{-} / \mathrm{NH}_{4}{ }^{+}$ & & & $* * *$ & $* *$ & $* *$ & ns & $* * *$ \\
\hline Put $X \mathrm{NO}_{3}{ }^{-} / \mathrm{NH}_{4}{ }^{+}$ & & & $* * *$ & $* * *$ & $* * *$ & ns & $* * *$ \\
\hline $\begin{array}{c}\text { T X Put X } \\
\mathrm{NO}_{3}{ }^{-} / \mathrm{NH}_{4}{ }^{+}\end{array}$ & & & $* * *$ & $* * *$ & $* * *$ & $* * *$ & $* * *$ \\
\hline
\end{tabular}

Different small letters within a column indicate significant differences among the different putrescine treatments, $\mathrm{NO}_{3}{ }^{-} / \mathrm{NH}_{4}{ }^{+}$ratios and temperatures ( $p=0.05$, Tukey test). Analysis of variance: ns, not significant; ${ }^{*} p \leq 0.05 ; * * p \leq 0.005 ;{ }^{* * *} p \leq 0.001$.

Table 5. Effect of the foliar application of putrescine on the concentrations of polyamines (nmoles $\mathrm{g}^{-1}$ ) in younger leaves of the cauliflower $\mathrm{cv}$. Moonshine at different $\mathrm{NO}_{3}{ }^{-} / \mathrm{NH}_{4}{ }^{+}$ratios and temperatures.

\begin{tabular}{|c|c|c|c|c|c|c|c|}
\hline Temperature & $\mathrm{NO}_{3}{ }^{-} / \mathrm{NH}_{4}{ }^{+}$ & & Putrescine & Cadaverine & Spermidine & Spermine & Total \\
\hline \multirow{6}{*}{$\begin{array}{c}\text { Ambient } \\
\text { temperature }\end{array}$} & \multirow{2}{*}{$100 / 0$} & Without Put & $23.12 \mathrm{~h}$ & $12.44 \mathrm{~d}$ & $17.72 \mathrm{~h}$ & $3.20 \mathrm{~h}$ & $51.84 \mathrm{i}$ \\
\hline & & With Put & $24.17 \mathrm{~g}$ & $16.14 \mathrm{bc}$ & $27.66 \mathrm{efg}$ & $4.45 \mathrm{fg}$ & $68.63 \mathrm{~h}$ \\
\hline & \multirow{2}{*}{$80 / 20$} & Without Put & $23.73 \mathrm{~g}$ & $15.93 \mathrm{c}$ & $24.80 \mathrm{~g}$ & $4.17 \mathrm{~g}$ & $71.02 \mathrm{~h}$ \\
\hline & & With Put & $25.15 \mathrm{f}$ & $16.68 \mathrm{abc}$ & 29.61 def & $4.54 \mathrm{fg}$ & $72.41 \mathrm{gh}$ \\
\hline & \multirow{2}{*}{$50 / 50$} & Without Put & $24.016 \mathrm{~g}$ & $16.12 \mathrm{bc}$ & $26.60 \mathrm{fg}$ & $4.29 \mathrm{fg}$ & $75.98 \mathrm{fgh}$ \\
\hline & & With Put & $26.33 \mathrm{e}$ & $17.03 \mathrm{abc}$ & $30.78 \mathrm{de}$ & $4.77 \mathrm{def}$ & $78.91 \mathrm{efg}$ \\
\hline \multirow{6}{*}{ High temperature } & \multirow{2}{*}{$100 / 0$} & Without Put & $27.00 \mathrm{~d}$ & $17.86 \mathrm{abc}$ & $31.73 \mathrm{~cd}$ & 5.01 cde & $81.59 \mathrm{def}$ \\
\hline & & With Put & $29.73 b$ & $18.71 \mathrm{abc}$ & $37.57 \mathrm{ab}$ & $5.42 \mathrm{abcd}$ & 84.60 cde \\
\hline & \multirow{2}{*}{$80 / 20$} & Without Put & $27.63 \mathrm{c}$ & $18.17 \mathrm{abc}$ & $33.44 \mathrm{~cd}$ & $5.37 \mathrm{bcd}$ & $86.97 \mathrm{bcd}$ \\
\hline & & With Put & $29.90 \mathrm{~b}$ & $19.05 \mathrm{ab}$ & $39.064 \mathrm{ab}$ & $5.94 \mathrm{ab}$ & $91.62 \mathrm{abc}$ \\
\hline & \multirow{2}{*}{$50 / 50$} & Without Put & $28.19 c$ & $18.19 \mathrm{abc}$ & $35.19 \mathrm{bc}$ & $5.61 \mathrm{abc}$ & $93.95 \mathrm{ab}$ \\
\hline & & With Put & 30.53 a & $19.44 \mathrm{a}$ & $40.96 \mathrm{a}$ & $6.11 \mathrm{a}$ & $97.05 \mathrm{a}$ \\
\hline \multicolumn{8}{|l|}{ Main effects } \\
\hline Temperature (T) & & & $* * *$ & $* * *$ & $* * *$ & $* * *$ & $* * *$ \\
\hline Putrescine (Put) & & & $* * *$ & ns & $* * *$ & $*$ & $* * *$ \\
\hline $\begin{array}{l}\text { Nitrate/ ammonium } \\
\quad\left(\mathrm{NO}_{3}-/ \mathrm{NH}_{4}^{+}\right)\end{array}$ & & & $* * *$ & ns & $* * *$ & $* * *$ & $* * *$ \\
\hline TXPut & & & ns & ns & ns & ns & ns \\
\hline $\mathrm{T} \times \mathrm{NO}_{3}{ }^{-} / \mathrm{NH}_{4}{ }^{+}$ & & & ns & ns & ns & ns & ns \\
\hline Put $X \mathrm{NO}_{3}{ }^{-} / \mathrm{NH}_{4}{ }^{+}$ & & & $* * *$ & ns & $* * *$ & $* * *$ & $* * *$ \\
\hline $\begin{array}{c}\text { T X Put X } \\
\mathrm{NO}_{3}^{-} / \mathrm{NH}_{4}^{+}\end{array}$ & & & $* * *$ & ns & ns & ns & ns \\
\hline
\end{tabular}

Different small letters within a column indicate significant differences among the different putrescine treatments, $\mathrm{NO}_{3}{ }^{-} / \mathrm{NH}_{4}{ }^{+}$ratios and temperatures $\left(p=0.05\right.$, Tukey test). Analysis of variance: ns, not significant; ${ }^{*} p \leq 0.05 ; * * * p \leq 0.001$. 
To our knowledge, although quite a lot of work has been published about the effects of polyamines on plants under salinity and drought stresses, there has been little work focused on polyamines in plants under heat stress. In addition, there are several different points of view on the relationship between polyamines and plant heat stress [47]. In this sense, several authors reported that an increase in spermidine and a decrease in putrescine were obtained as a consequence of the exposure of plants to heat stress [44]. However, in our work, the contents of all polyamines increased as a result of a short-term exposure to high temperature. These results are consistent with a report that endogenous leaf polyamines in Chinese kale were increased after 6 days of high-temperature treatment [5]. Polyamines perform a large number of functions in plants, including promotion of photosynthesis and increasing the antioxidant capacity and osmotic adjustment ability (as already indicated in the sugars) in order to reduce the damage caused by different types of stress. The controversy regarding the accumulation of these metabolites must be due to the fact that the main physiological mechanisms of tolerance of high temperatures differ among plant species and among the stages of plant maturation [38]. The results in Tables 4 and 5 show that, as happened with the TPC, polyamines accumulated in those cauliflower plants whose nutrient solution was more enriched with ammonium. This is supported by several authors who proposed that the content of polyamines is raised to high levels by ammonium nutrition in order to enhance plant tolerance of stresses [28]. Although the roles of polyamines have been assigned mainly to floral induction, reproductive processes and root formation, a growing body of evidence points to an important role in the management of nitrogen stresses. For this, polyamines act as nitrogen reserves or deposits and as free radical scavengers in order to maintain the integrity of the membranes and, consequently, protect cells from nitrogen toxicity [28].

The exogenous polyamine treatment increased the endogenous polyamine content. This is consistent with other studies that reported that exogenous polyamine application can increase the polyamines content in plants, which can lead to a decline in reactive oxygen species and thus in the negative effects of abiotic stress, improving plant quality and even delaying senescence [38].

From a nutritional point of view, although in cauliflower waste no new compounds were found compared to the edible part, the non-edible part is a good and cheap source of some bioactive compounds-phenolics, sugars, and polyamines, among others. Some nutritional studies have indicated that there is a relationship between polyamine-rich foods and a lower risk of cardiovascular diseases, better conservation of memory and greater longevity [11]. Therefore, it could be interesting to apply this new strategy (the combination of a short heat stress, a nutrient solution with a 50:50 $\mathrm{NO}_{3}{ }^{-} / \mathrm{NH}_{4}{ }^{+}$ratio and foliar application of putrescine) to promote the incorporation of these cauliflower by-products into nutraceutical and pharmaceutical preparations for human health.

\section{Conclusions}

Based on all these results, we can conclude that the use of putrescine and an ammonium ratio of $50 \%$ at a high temperature gave rise to plants with greater biomass and a higher content of bioactive compounds. The young leaves showed the greatest biomass and were the site where the biosynthesis of interesting bioactive compounds was mainly promoted. The stimulation of polyamines accumulation in the cauliflower cv. Moonshine by the use of the combination of a short heat stress, a nutrient solution with a 50:50 $\mathrm{NO}_{3}{ }^{-} / \mathrm{NH}_{4}{ }^{+}$ratio, and foliar application of putrescine can transform its waste into a very rich source of polyamines. Consequently, the development of this new strategy in cauliflower to obtain improved wastes has promising prospects for the pharmaceutical, cosmetics and food industries. The processing of these wastes would have another advantage since their environmental impact would be greatly reduced. 
Supplementary Materials: The supplementary materials are available at https:/ / www.mdpi.com/ article/10.3390/antiox10050707/s1.

Author Contributions: J.C.-G.: Conceptualization, Methodology, Formal analysis, Investigation, Writing, and Editing. M.C.P.: Methodology, Formal analysis, and Investigation. G.O.: Methodology, Formal analysis, and Investigation. J.L.-M.: Supervision. F.M.d.A.: Conceptualization, Funding acquisition, Resources, Project administration, and Supervision. All authors have read and agreed to the published version of the manuscript.

Funding: This work was financed by the European Regional Development Fund (ERDF) $80 \%$ Región de Murcia (FEDER 1420-30).

Institutional Review Board Statement: Not applicable.

Informed Consent Statement: Not applicable.

Data Availability Statement: Data is contained within the article and supplementary material.

Acknowledgments: We thank José Manuel Gambín, Miguel Marín, José Sáez, and Raquel Roca, for technical assistance.

Conflicts of Interest: The authors declare that they do not have any conflict of interest.

\section{References}

1. IPCC. Special Report on Global Warming of 1.5 C (SR15); IPCC: Geneva, Switzerland, 2018.

2. Khan, K.A.; Zaman, K.; Shoukry, A.M.; Sharkawy, A.; Gani, S.; Ahmad, J.; Khan, A.; Hishan, S.S. Natural disasters and economic losses: Controlling external migration, energy and environmental resources, water demand, and financial development for global prosperity. Environ. Sci. Pollut. Res. 2019, 26, 14287-14299. [CrossRef] [PubMed]

3. Soengas, P.; Rodríguez, V.M.; Velasco, P.; Cartea, M.E. Effect of temperature stress on antioxidant defenses in Brassica oleracea. ACS Omega 2018, 3, 5237-5243. [CrossRef] [PubMed]

4. Zhang, D.; Ren, L.; Chen, G.-q.; Zhang, J.; Reed, B.M.; Shen, X.-h. ROS-induced oxidative stress and apoptosis-like event directly affect the cell viability of cryopreserved embryogenic callus in Agapanthus praecox. Plant Cell Rep. 2015, 34, 1499-1513. [CrossRef] [PubMed]

5. Hussain, S.S.; Ali, M.; Ahmad, M.; Siddique, K.H. Polyamines: Natural and engineered abiotic and biotic stress tolerance in plants. Biotechnol. Adv. 2011, 29, 300-311. [CrossRef]

6. Nortes, P.; Baille, A.; González-Real, M.; Ruiz-Salleres, I.; Verhoef, A.; Martin-Gorriz, B.; Egea, G. Effects of high temperature and vapour pressure deficit on net ecosystem exchange and energy balance of an irrigated orange orchard in a semi-arid climate (Southern Spain). In Proceedings of the XXVIII International Horticultural Congress on Science and Horticulture for People (IHC2010): International Symposium, Lisbon, Portugal, 22 August 2010; pp. 149-156.

7. Pérez, F.L. Viticultural practices in Jumilla (Murcia, Spain): A case study of agriculture and adaptation to natural landscape processes in a variable and changing climate. AIMS Agric. Food 2016, 1, 265-293. [CrossRef]

8. Faostat. Agriculture Organization of the United Nations Statistics Division 2014. Production. 2016. Available online: http: / / faostat3.fao.org/browse/Q/QC/S (accessed on 17 December 2020).

9. Ministry of Agriculture, Fisheries and Food. Available online: https://www.mapa.gob.es/es/estadistica/temas/publicaciones/ anuario-de-estadistica $/ 2019 /$ default.aspx?parte=3\&capitulo=07\&grupo=6\&seccion=32 (accessed on 18 October 2020).

10. Kapusta-Duch, J.; Szelag-Sikora, A.; Sikora, J.; Niemiec, M.; Gródek-Szostak, Z.; Kuboń, M.; Leszczyńska, T.; Borczak, B. Health-Promoting Properties of Fresh and Processed Purple Cauliflower. Sustainability 2019, 11, 4008. [CrossRef]

11. Muñoz-Esparza, N.C.; Latorre-Moratalla, M.L.; Comas-Basté, O.; Toro-Funes, N.; Veciana-Nogués, M.T.; Vidal-Carou, M.C. Polyamines in Food. Front. Nutr. 2019, 6, 00108. [CrossRef]

12. Picchi, V.; Fibiani, M.; Scalzo, R.L. Cauliflower. In Nutritional Composition and Antioxidant Properties of Fruits and Vegetables; Academic Press: Cambrige, MA, USA, 2020; Volume 1, pp. 19-32.

13. Huynh, T.N. Biological Treatments of Cauliflower (Brassica oleracea L. var. botrytis) Outer Leaves: Improved Extraction and Conversion of Phenolic Compounds. Ph.D. Thesis, Ghent University, Ghent, Belgium, 2016.

14. Khedkar, M.A.; Nimbalkar, P.R.; Chavan, P.V.; Chendake, Y.J.; Bankar, S.B. Cauliflower waste utilization for sustainable biobutanol production: Revelation of drying kinetics and bioprocess development. Bioprocess Biosyst. Eng. 2017, 40, 1493-1506. [CrossRef]

15. Llorach, R.; Espín, J.C.; Tomás-Barberán, F.A.; Ferreres, F. Valorization of cauliflower (Brassica oleracea L. var. botrytis) by-products as a source of antioxidant phenolics. J. Agric. Food Chem. 2003, 51, 2181-2187. [CrossRef]

16. Coman, V.; Teleky, B.-E.; Mitrea, L.; Martău, G.A.; Szabo, K.; Călinoiu, L.-F.; Vodnar, D.C. Bioactive potential of fruit and vegetable wastes. Adv. Food Nutr. Res. 2020, 91, 157-225.

17. Orlando, M.; Trivellini, A.; Bartolini, S.; Carmassi, G.; Maggini, R.; Lucchesini, M.; Ferrante, A.; Incrocci, L.; Mensuali, A. Evaluation of by-products of plant food (potato and apple) as potential biostimulants for green leafy vegetables. In Proceedings 
of the III International Symposium on Growing Media, Composting and Substrate Analysis, Milan, Italy, 24-28 June 2019; Volume 1305, pp. 529-536.

18. Pirintsos, S.; Munzi, S.; Loppi, S.; Kotzabasis, K. Do polyamines alter the sensitivity of lichens to nitrogen stress? Ecotoxicol. Environ. Saf. 2009, 72, 1331-1336. [CrossRef]

19. Mostafaei, E.; Zehtab-Salmasi, S.; Salehi-Lisar, Y.; Ghassemi-Golezani, K. Changes in photosynthetic pigments, osmolytes and antioxidants of Indian Mustard by drought and exogenous polyamines. Acta Biol. Hung. 2018, 69, 313-324. [CrossRef]

20. Pang, X.-M.; Zhang, Z.-Y.; Wen, X.-P.; Ban, Y.; Moriguchi, T. Polyamines, all-purpose players in response to environment stresses in plants. Plant Stress 2007, 1, 173-188.

21. Collado-González, J.; Piñero, M.C.; Otálora, G.; López-Marín, J.; del Amor, F.M. Effects of Different Nitrogen Forms and Exogenous Application of Putrescine on Heat Stress of Cauliflower: Photosynthetic Gas Exchange, Mineral Concentration and Lipid Peroxidation. Plants 2021, 10, 152. [CrossRef]

22. Luna-Esquivel, E.N.; Ojeda-Barrios, D.L.; Guerrero-Prieto, V.M.; Ruiz-Anchondo, T.; Martínez-Téllez, J.J. Poliaminas como indicadores de estrés en plantas. Rev. Chapingo Ser. Hortic. 2014, 20, 283-295. [CrossRef]

23. Gupta, K.; Dey, A.; Gupta, B. Plant polyamines in abiotic stress responses. Acta Physiol. Plant. 2013, 35, 2015-2036. [CrossRef]

24. Kotakis, C.; Theodoropoulou, E.; Tassis, K.; Oustamanolakis, C.; Ioannidis, N.E.; Kotzabasis, K. Putrescine, a fast-acting switch for tolerance against osmotic stress. J. Plant Physiol. 2014, 171, 48-51. [CrossRef]

25. Mirdehghan, S.; Rahimi, S. Pre-harvest application of polyamines enhances antioxidants and table grape (Vitis vinifera L.) quality during postharvest period. Food Chem. 2016, 196, 1040-1047. [CrossRef]

26. Hord, N.G.; Tang, Y.; Bryan, N.S. Food sources of nitrates and nitrites: The physiologic context for potential health benefits. Am. J. Clin. Nutr. 2009, 90,1-10. [CrossRef]

27. Petropoulos, S.A.; Fernandes, Â.; Calhelha, R.C.; Di Gioia, F.; Kolovou, P.; Barros, L.; Ferreira, I.C. Chemical composition and bioactive properties of Cichorium spinosum L. in relation to nitrate/ammonium nitrogen ratio. J. Sci. Food Agric. 2019, 99, 6741-6750. [CrossRef]

28. Munene, R.; Changamu, E.; Korir, N.; Joseph, G.-O. Effects of different nitrogen forms on growth, phenolics, flavonoids and antioxidant activity in amaranth species. Trop. Plant Res. 2017, 4, 81-89. [CrossRef]

29. Del Amor, F.M.; Cuadra-Crespo, P.; Walker, D.J.; Cámara, J.M.; Madrid, R. Effect of foliar application of antitranspirant on photosynthesis and water relations of pepper plants under different levels of $\mathrm{CO}_{2}$ and water stress. J. Plant Physiol. 2010, 167, 1232-1238. [CrossRef]

30. Kähkönen, M.P.; Hopia, A.I.; Vuorela, H.J.; Rauha, J.-P.; Pihlaja, K.; Kujala, T.S.; Heinonen, M. Antioxidant activity of plant extracts containing phenolic compounds. J. Agric. Food Chem. 1999, 47, 3954-3962. [CrossRef]

31. Cano-Lamadrid, M.; Hernández, F.; Corell, M.; Burló, F.; Legua, P.; Moriana, A.; Carbonell-Barrachina, Á.A. Antioxidant capacity, fatty acids profile, and descriptive sensory analysis of table olives as affected by deficit irrigation. J. Sci. Food Agric. 2017, 97, 444-451. [CrossRef]

32. Balibrea, M.E.; Cuartero, J.; Bolarín, M.C.; Pérez-Alfocea, F. Sucrolytic activities during fruit development of Lycopersicon genotypes differing in tolerance to salinity. Physiol. Plant. 2003, 118, 38-46. [CrossRef]

33. Rodriguez, S.; López, B.; Chaves, A.R. Effect of different treatments on the evolution of polyamines during refrigerated storage of eggplants. J. Agric. Food Chem. 2001, 49, 4700-4705. [CrossRef]

34. Coleto, I.; Vega-Mas, I.; Glauser, G.; González-Moro, M.B.; Marino, D.; Ariz, I. New insights on Arabidopsis thaliana root adaption to ammonium nutrition by the use of a quantitative proteomic approach. Int. J. Mol. Sci. 2019, 20, 814. [CrossRef]

35. Hu, L.; Yu, J.; Liao, W.; Zhang, G.; Xie, J.; Lv, J.; Xiao, X.; Yang, B.; Zhou, R.; Bu, R. Moderate ammonium: Nitrate alleviates low light intensity stress in mini Chinese cabbage seedling by regulating root architecture and photosynthesis. Sci. Hortic. 2015, 186, 143-153. [CrossRef]

36. Juan, L.; Zhou, J.-M.; Duan, Z.-Q. Effects of elevated $\mathrm{CO}_{2}$ concentration on growth and water usage of tomato seedlings under different ammonium/nitrate ratios. J. Environ. Sci. 2007, 19, 1100-1107.

37. Röth, S.; Paul, P.; Fragkostefanakis, S. Plant heat stress response and thermotolerance. In Genetic Manipulation in Plants for Mitigation of Climate Change; Springer: New Delhi, India, 2015; pp. 15-41.

38. Chen, D.; Shao, Q.; Yin, L.; Younis, A.; Zheng, B. Polyamine function in plants: Metabolism, regulation on development, and roles in abiotic stress responses. Front. Plant Sci. 2019, 9, 1945. [CrossRef] [PubMed]

39. Zulfiqar, F.; Akram, N.A.; Ashraf, M. Osmoprotection in plants under abiotic stresses: New insights into a classical phenomenon. Planta 2020, 251, 1-17. [CrossRef] [PubMed]

40. Yang, B.; Wu, J.; Gao, F.; Wang, J.; Su, G. Polyamine-induced nitric oxide generation and its potential requirement for peroxide in suspension cells of soybean cotyledon node callus. Plant Physiol. Biochem. 2014, 79, 41-47. [CrossRef] [PubMed]

41. Collado-González, J.; Piñero, M.C.; Otálora, G.; López-Marín, J.; del Amor, F.M. Exogenous spermidine modifies nutritional and bioactive constituents of cauliflower (Brassica oleracea var. botrytis L.) florets under heat stress. Sci. Hortic. 2021, $277,109818$. [CrossRef]

42. Bhandari, S.R.; Kwak, J.-H. Chemical composition and antioxidant activity in different tissues of Brassica vegetables. Molecules 2015, 20, 1228-1243. [CrossRef]

43. Martínez-Sánchez, A.; Gil-Izquierdo, A.; Gil, M.I.; Ferreres, F. A comparative study of flavonoid compounds, vitamin C, and antioxidant properties of baby leaf Brassicaceae species. J. Agric. Food Chem. 2008, 56, 2330-2340. [CrossRef] 
44. Toscano, S.; Trivellini, A.; Cocetta, G.; Bulgari, R.; Francini, A.; Romano, D.; Ferrante, A. Effect of Preharvest Abiotic Stresses on the Accumulation of Bioactive Compounds in Horticultural Produce. Front. Plant Sci. 2019, 10, 1212. [CrossRef]

45. Mostafa, H.A.M.; Hassanein, R.A.; Khalil, S.I.; El-Khawas, S.A.; El-Bassiouny, H.M.S.; El-Monem, A.A.A. Effect of arginine or putrescine on growth, yield and yield components of late sowing wheat. Res. J. Appl. Sci. 2010, 177-183.

46. Dong, S.; Beckles, D.M. Dynamic changes in the starch-sugar interconversion within plant source and sink tissues promote a better abiotic stress response. J. Plant Physiol. 2019, 234, 80-93. [CrossRef]

47. Xia, J.L.; Wu, C.G.; Ren, A.; Hu, Y.R.; Wang, S.L.; Han, X.F.; Shi, L.; Zhu, J.; Zhao, M.W. Putrescine regulates nitric oxide accumulation in Ganoderma lucidum partly by influencing cellular glutamine levels under heat stress. Microbiol. Res. 2020, $239,126521$. [CrossRef] 